\title{
PASANDO LA TURQUESA Objetos Azules del Valle de Ónavas, Sonora, México
}

\author{
TURQUOISE PASSING BY \\ Blue Items from The Onavas Valley, Sonora, Mexico
}

\author{
Emiliano Gallaga Murrieta ${ }^{1}$ \\ gallagam@gmail.com \\ Emiliano Ricardo Melgar Tísoc ${ }^{2}$ \\ melgare@hotmail.com
}

\section{RESUMEN}

En el Valle de Ónavas, Sonora, México, en la zona media del río Yaqui, se encontraron varias piezas de verde claro a un material de color verde o azul intenso visualmente identificado turquesa durante un trabajo de campo realizado allí en 2004. Se suponía que la fuente de este material provenía del suroeste americano, aunque hay que reconocer que existen ciertas fuentes de turquesa en Sonora, que pueden haber sido explotadas también en la época prehispánica. En este texto se presentan nuevos estudios sobre la turquesa identificada, las posibles fuentes de las piezas de color turquesa del Valle de Ónavas y las posibles implicaciones de gran alcance de estos resultados.

Palabras clave: Turquesa, tecnología, materias primas, minerales.

${ }^{1}$ Docente, Facultad de Gestión Turística, Universidad Autónoma de Chiapas.

${ }^{2}$ Docente, Instituto Nacional de Antropología e Historia, Museo del Templo Mayor. 


\title{
ABSTRACT
}

In the Onavas Valley, Sonora, Mexico, in the middle Yaqui River area, several pieces of light green to an intense green or blue color material visually identified turquoise were found during a survey conducted there in 2004. The source of this material was supposed to be from the American Southwest, though it must be recognized that certain sources of turquoise exist in Sonora, which may have been exploited in pre-Hispanic times as well. This paper presents new research about turquoise identification, possible sources of the Onavas Valley turquoise pieces and the potential far-reaching implications of these results.

Keywords: Turquoise, technology, raw material, minerals.

\section{RESEARCH CONTEXT}

\author{
They adorned their ears by piercing \\ the edge of the ear and hanging \\ some little charms from ribbons of \\ blue cotton thread. Even the men \\ did this, in addition to hanging some \\ small, valuable emerald-like stones \\ [turquoise?] from the cartilage of \\ their nose (PÉREZ DE RIBAS, 1999:329).
}

Like this, many other colonial documents present similar descriptions on how the local indigenous people in and out of the Mesoamerica realm use blue/green stones as decoration, garments, prestigious item, or simply to illustrated how precious this color was for them more than the stone. In the archaeological context, the appearance of this blue color stones, call it turquoise, malachite, amazonite, chrysocolla, or azurite, is quite abundant with more of one million pieces recorded of it as beads or decorating very complex and elaborate objects found in elites tombs or as offerings. Because little research had been done on this 
raw material per se, like many other items and materials for the Mesoamerican context such as pyrite or cinnabar, researchers normally accept two common statements about this material: 1) if its blue most be turquoise, and 2) if is turquoise, most came from the American Southwest prehispanic mines. In reality, the spectrum is by far more diverse than we thought. Very recent research on this particular topic, illustrated that indeed "chemical" turquoise (real or geological turquoise) is present in Mesoamerica, and indeed some of it came from the prehispanic mines of the American Southwest. But also, shows that "cultural" turquoise (a range of blue-green minerals, including turquoise, malachite, amazonite, chrysocolla, or azurite) is present as well and had been worked in the area as much as the "chemical" turquoise, but with more diverse sources like those located in Arizona and New Mexico in the United States and Chalchihuites (Zacatecas) and Ameca (Jalisco) in Mexico. In addition, other "chemical" turquoise prehispanic sources are been identified as well, one of them will be presented in this paper.

On the other hand, in spite of the sources and the type of the turquoise used (chemical or cultural), is clear that this material had to be transport from the source to the desire destination, in some cases far, very far away, like those "chemical" turquoise from the site of Chichén Itzá that came from the Cerrillos mines of Nuevo México (WEIGAND, 1997: 30). In this paper, we will focus on an area we think could have a participation on the trade routes from the American Southwest / Northwest Mexico through the northern realm of Mesoamerica, the 
Onavas Valley of Sonora, Mexico, which recently had been in the spotlight after establishing clear cultural connections with northern Mesoamerica from burials from a prehispanic cemetery mound (GALLAGA, 2013; INAH, 2012).

\section{THE ONAVAS VALLEY}

The Onavas Valley lies in the south central part of Sonora, Mexico $\left(28^{\circ} 28^{\prime} \mathrm{N}\right.$, $109^{\circ} 32^{\prime} \mathrm{W}, 150 \mathrm{~m}$ above sea level) (Figure 1). The town of Onavas, the center of the Onavas Valley Archaeological Project (OVAP) research area, is a small agricultural community of approximately 450 inhabitants. Jesuit Father Diego Vandersipe founded a mission there in 1622 with the name of San Ignacio de Onavas. Today, the village serves as the cabecera (administrative center) of the municipio (equivalent to a U.S. county) with the same name (ALMADA, 1990: 468). The village of Onavas is located two hours driving distance $(200 \mathrm{~km})$ from the city of Hermosillo, which is the capital of the state of Sonora. 


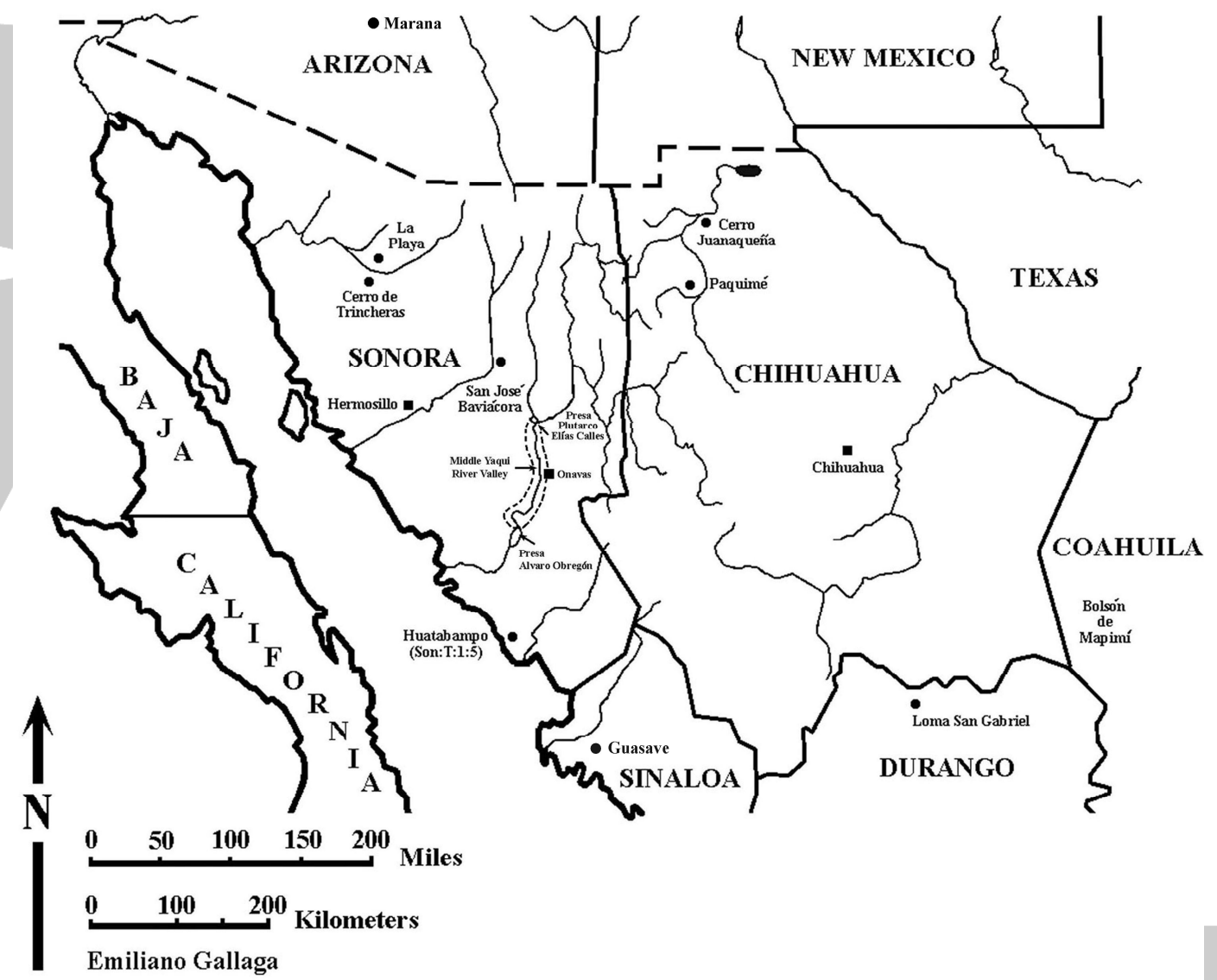

Figure 1: Location of Onavas Valley in the Middle Río Yaqui region and points of comparison in the Northwest (by Emiliano Gallaga). 
The study area lies in the middle of the ecological sub-province of Sonora in the Middle Río Yaqui Valley which is characterized by parallel mountain ridges and valleys. Due to its location, this area functions as a transition zone between the Sierra Madre Occidental and the Sonoran Desert. The climatic and topographic characteristics of this region are shaped by the proximity of the Sierra Madre Occidental and the Gulf of California. The Sierra Madre Occidental consists of high volcanic table lands and ranges, and extends from eastern Sonora and western Chihuahua to Jalisco in central Mexico. These systems of mountain ranges are rugged and range in elevation from 800 to $2,000 \mathrm{~m}$ above the river valleys. All major rivers in Sonora originate high in the Sierra Madre Occidental and have carved out deep, jagged canyons or barrancas in the Sierra (ALMADA, 1990; MONTANE, 1993; PÉREZ BEDOLLA, 1996; WEST, 1993).

The Onavas Valley is part of the Río Yaqui drainage system. The largest and most economically important river in the state of Sonora, the Río Yaqui has a mean annual discharge of 90,000,000 $\mathrm{m}^{3}$ of water, extends about $740 \mathrm{~km}$, and drains a watershed of some 80,000 km² (PÉREZ BEDOLLA 1996: 116). The Río Yaqui originates to the west of the Sierra Madre at the junction of the Río Papigochic and Río Bavispe. On its way south to the coast, the major tributaries of the Río Yaqui are the Río Sahuaripa, Bacanora, Moctezuma, Chico, and Tecoripa. Below the Alvaro Obregón dam, the river changes its course westward to drain into the Gulf of California (PÉREZ BEDOLLA, 1996: 116). Currently, the Río Yaqui is the only river in Sonora that flows year-round. Previous to the construction of the 
Alvaro Obregón (1952) and El Novillo (1963) dams, the Río Yaqui had seasonal floods that irrigated and fertilized an extensive floodplain.

As rugged as the Sierra province is, river valleys form logical routes to travel through the Sierra connecting the Sonoran coast with the interior and vice versa. For example, the Onavas Valley is located between 140 to $240 \mathrm{~km}$ from the Sonoran coast and around 300 to $350 \mathrm{~km}$ west of the Sierra from the Casas Grandes region. Although the distance between these areas does not amount to much, the terrain is difficult and must have taken several days to cross by foot in Prehispanic times. Therefore, the Río Yaqui and its tributaries, provides a logical route of commerce and communication between several cultural areas. The finding of several sherds from the Casas Grandes ceramic traditions at Onavas sites prove that there was some type of contact between this valley and Paquimé on the other side of the Sierra Madre (GALLAGA, 2013).

\section{THE BLUE STONES FROM THE ONAVAS VALLEY ARCHAEOLOGICAL PROJECT (OVAP)}

The OVAP, conducted archaeological investigations between the modern Alvaro Obregón and El Novillo dams, and was obliged to begin by building a basic archaeological database for the region in order to increase our still fragmentary understanding of the late Prehispanic context of Northwest Mexico. A fullcoverage systematic pedestrian survey was undertaken to define the cultural history of the Onavas Valley and to examine extra-regional interactions between 
the valley and surrounding areas. The OVAP field work lasted 10 weeks, from early June to mid-August of 2004, with the Onavas town serving as the middle point of the research area. At the end of the field season, the archaeologists had covered more than $67 \mathrm{~km}^{2}$ and collected from the surface a total of 10740 sherds-(more than $113.550 \mathrm{~kg}$ of ceramic material)—, 2363 lithic items (more than $64 \mathrm{~kg}$ ), and 1191 marine shell pieces (1.113 kg) (GALLAGA, 2013).

The archaeological material analyses completed by the OVAP were geared towards defining and describing material types and varieties to summarize the material assemblage of the Onavas Valley Prehispanic communities. The material analysis focused on obtaining both stylistic and functional information, as well as regional and extra-regional interactions. From the total amount of the lithic material collected, 1871 debitage flakes and cores $(15.948 \mathrm{~kg}), 231$ pieces of obsidian $(0.252 \mathrm{~kg}), 125$ pieces of stone tools $(46.515 \mathrm{~kg}), 21$ bifacial tools $(0.815$ $\mathrm{kg}), 107$ projectile points $(0.502 \mathrm{~kg})$, and 15 pieces of "turquoise" $(0.019 \mathrm{~kg})$ were identified.

From the total of pieces found of allegedly turquoise material, seven were pendants, four beads, and three classified as raw material (Figure 2). The turquoise items show fine texture surface and colors that ran from light green to an intense green or blue. At that time of the project, these materials were identified as such only by visual examination. 


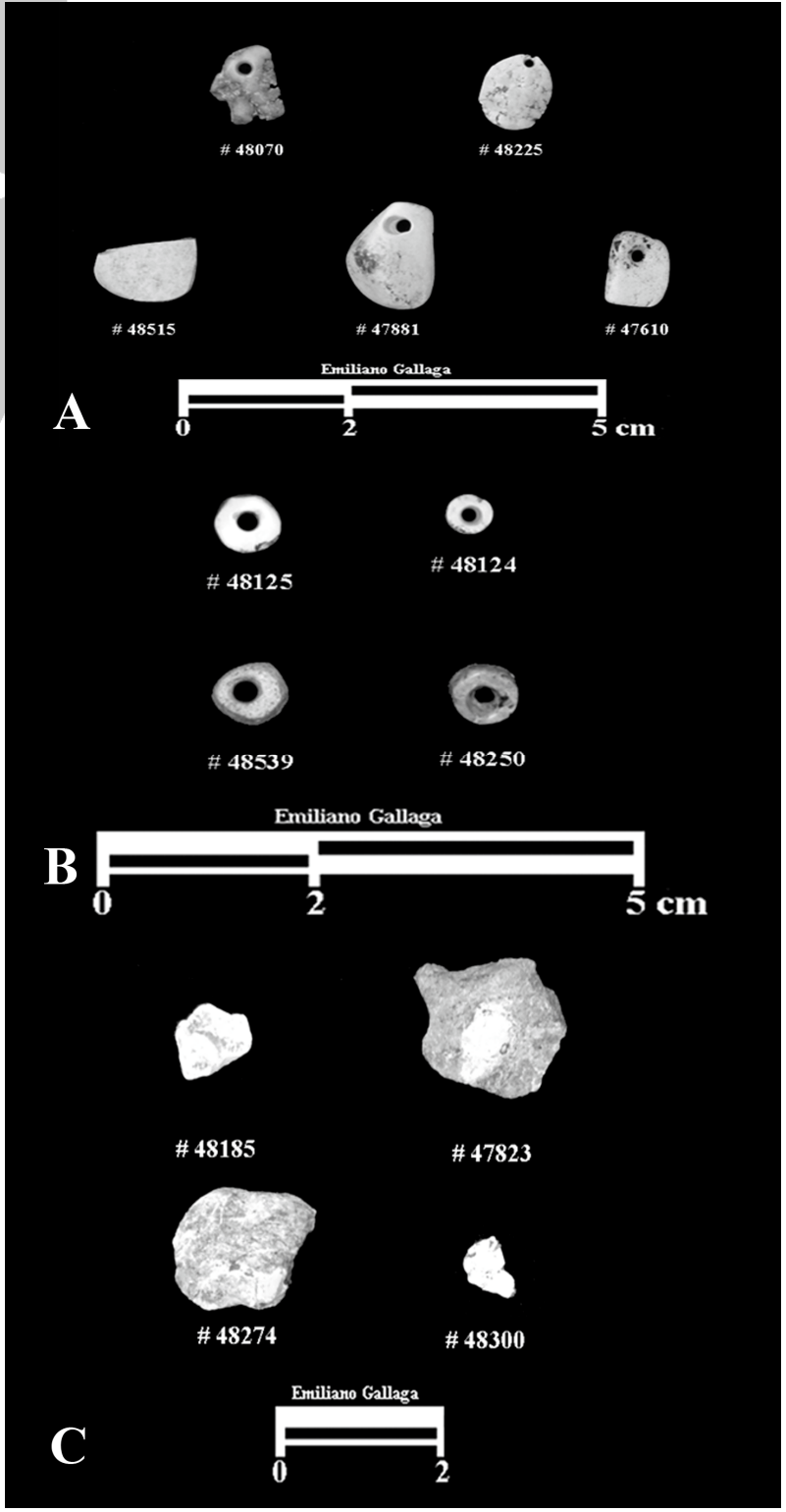

Figure $\quad 2: \quad$ Turquoise archaeological material from Onavas Valley: Pendants (A), 
beads (B), and raw material (C). (Photos by Emiliano Gallaga).

Pendants (\# 7). All the turquoise pendants were flat plates that have been smoothed, and perforated with a suspension hole located nearer one end. Six of the seven turquoise pendants were rectangular in shape and measure on average $11 \times 6.5 \mathrm{~mm}$ and $2 \mathrm{~mm}$ thick, while the last one was almost circular in shape (\# 48225). Three pendants had a conic perforation, two had a bi-conic perforation, and the rest remained unknown as they were fragments without perforation. One of them found at the cemetery mound site (SON P: 08).

Beads (\# 4). All the stone beads registered by the OVAP were made of turquoise. These items were "perforated with a suspension hole that extends approximately through the middle from side to side so that the edge or perimeter of the ornament is most visible when strung" (ADAMS, 1997: 28). On average they measured $5.55 \mathrm{~mm}$ in diameter, were of circular shape, and two had a conic perforation and two had a bi-conical perforation.

Raw Material (\# 3). Three pieces were identified to be raw material, they did not show evidence of been work in any way, and were collected for its color. These pieces had an average dimension of $2 \times 2 \times 2 \mathrm{~cm}$.

Although, the amount of presumably turquoise was small only $0.019 \mathrm{~kg}$, was very significant due that its presence in the valley poses interesting research questions: was this material exploited locally in Sonora or did it arrive through trade from 
the U.S. Southwest? To what degree and in what form did Prehispanic Sonoran communities participate in the mining and manufacture of turquoise, or did they trade for finished products? Material evidence from sites in the region illustrate that turquoise is very common in Sonora. In Huatabampo, more than 200 turquoise pieces were reported (Alvarez, 1990:58-62). At the Guasave site, 99 pieces were found (EKHOLM, 1942: 105) and sites along the Río Alamos in Sinaloa have yielded some turquoise pieces as well (Carpenter, personal communication 2005). Descriptions of nearby cultural groups also offer possible indications of the use of certain materials. Pérez de Ribas (1999: 329) emphasizes the use of cotton, turquoise, and the color blue as corporal decoration among the Yaqui. He also makes emphasis that almost all the Indian nations from the region decorated themselves accordingly. Fifteen turquoise pieces were recorded in surface by the OVAP confirming the use and circulation of this material in the area. That Pérez de Ribas mentions the use of turquoise among the Yaquis may further point to interregional interactions and suggests that this precious material could be obtained via the Río Yaqui, which passes through the Onavas Valley. However, to answer these questions it is necessary to establish if those blue stones are actually turquoise and, if possible, the source from where they are coming from. In addition, to know how those pieces were made? and it is possible to determine if they could be made by the Nebomes of the Onavas Valley? (GALLAGA, 2013).

\section{METHODOLOGY}


Two lines of analysis were employed in this process: 1) one to establish if the blue stone collected in the Onavas Valley was "chemical" or "cultural" turquoise; and 2) establish the manufacture process of the pieces. In order to do this, we establish a research collaboration with the "Style and Technology of the Lapidary Objects in Ancient Mexico Project" run by the archaeologist Emiliano Melgar from the Templo Mayor Museum. This project has the objective to discern the prehispanic methods or techniques used in the production of lapidary objects through the application of the experimental archaeology paradigm (MELGAR AND SOLÍS, 2009; MELGAR et al., 2010). This paradigm works from the assumption that every single item manufactured in the past was regulated by cultural patterns of production that provide particular characteristics to the object in question. So, the reproduction of such manufacture processes, techniques used, as well as similar tools, must obtain similar results to those objects made in the past with similar production traces or patterns (ASCHER, 1961; VELÁZQUEZ, 2007). After several years of research, this workshop was able to reproduce the different types of modifications that the objects present, using same materials, similar working tools and processes referred to in historical sources, found in archaeological context, and proposed by colleagues (MELGAR AND SOLÍS, 2009; MELGAR et al., 2010). The resulting prints or traces are systematically compared with those found at the archaeological artifacts at glance, using a 20x magnifying glass, and through the use of a stereoscopic microscope at 10x, 30x and 63x. As well as through a Scanning Electron Microscopy (SEM) to 100x, 300x, 600x and 1000x, under constant parameters (HV mode, $10 \mathrm{~mm}$ of work distance, SEI signal, 
voltage of $20 \mathrm{kV}$, and spotsize of 47). Thus, the surface features observed are described as the direction and size of bands and lines, and its texture roughness, following the same methodology proposed by Adrian Velázquez (2007) for the shell material analysis, but adapted for other archaeological material as well. The optical microscope used in this analysis is in the Templo Mayor Museum and the Scanning Electron Microscope is in the Electron Microscopy Laboratory of the Division of Laboratories and Academic Support INAH, in charge of Mr. Gerardo Villa.

For the analysis of the chemical composition of the stone, we like to address that these materials have been analyzed with different non-invasive and nondestructive techniques in collaboration with Dr. José Luis Ruvalcaba and the staff of the Physics Institute of UNAM, to know their mineralogical composition and identification. The techniques used were Ultra Violet Light Fluorescence (UVF), infrared light (IRF) and X-ray Fluorescence (XRF), Spectrometry Emission of Xray by Induced Particles (PIXE), Infrared Spectroscopy (FTIR), and Elastic Backscatter of particles (RBS), among others (RUVALCABA et al., 2005; LACLAVETINE, 2008).

\section{TO BE BLUE OR NOT TO BE BLUE? THAT IS THE QUESTION.}

At the time of the OVAP project in 2004 the presence of supposedly turquoise material, indicate either exploitation of a local sources or trade of raw material / finished objects from areas outside the valley. A lack of research on turquoise in 
the Onavas Valley leads to the assumption that these turquoise items or raw materials possibly originated somewhere in the U. S. Southwest, probably from sources in New Mexico, such as Cerrillos or the Azure site, or in Arizona, such as Courtland or Gleason (EKHOLM, 1942; PAILES, 1980; WEIGAND AND HARDBOTTLE, 1993). However, local turquoise sources exist in the Sierra Madre Occidental, but the paucity of archaeological research or analysis prohibits any determination as to the use or degree of use of these Sonoran sources during the Prehispanic period (ALVAREZ, 1990; POGUE, 1912; WEIGAND AND HARDBOTTLE, 1993, 1995). Weigand and Hardbottle mention seven mines or sources of turquoise in northeast Sonora that were probably used in Prehispanic times. The sources are Cananeita, Campo Frío, Arroyo Cuitaca, Los Campito, Nacozari de García, El Verde, and San Felipe, but no further information is provided or actually testing of them (WEIGAND AND HARDBOTTLE, 1993: 162-163). Of those sources, the El Verde and Nacozari mines are the closest to the Onavas Valley, located about $200 \mathrm{~km}$ away to the north. Hence, was possible that the turquoise found and used in the Onavas Valley originated from these Sonoran sources and not from the U.S. Southwest.

To determine if the samples were or not turquoise, 14 of the blue stones from the Onavas Valley were analyzed. The results from the Infrared Spectroscopy (FTIR), Ultra-Violet Light Fluorescence (UVF), and Infrared Reflectance (IRR), show that 13 of them were actually "chemical" turquoise (Figure 3), and only one was a "cultural" turquoise, a green/blue chalcedony to be more accurate (Figure 4). 
Although is too early to be $100 \%$ certain, the FTIR and XRF analyses also show something more interesting, none of these stones came from the traditional prehispanic mines of Arizona or New Mexico in the states. A preliminary comparison with a sample from the mines of Cananea, Sonora, illustrated that samples from Onavas had a very close relationship. However, the X-ray spectrum shows that the quantities (percentage and intensity) of some chemical elements change in some points, especially on Zinc. Also, the presence of this element in the Cananea sample and Onavas pieces is the reason that they show a light or pale blue color, but the Onavas samples had a lot more Zinc. Apparently, Cananea could not be the source of the "chemical" turquoise of Onavas, but they came from a nearby area from it. Definitively more sampling is necessary, but we can establish that Sonoran turquoise sources are playing in the prehispanic markets. 


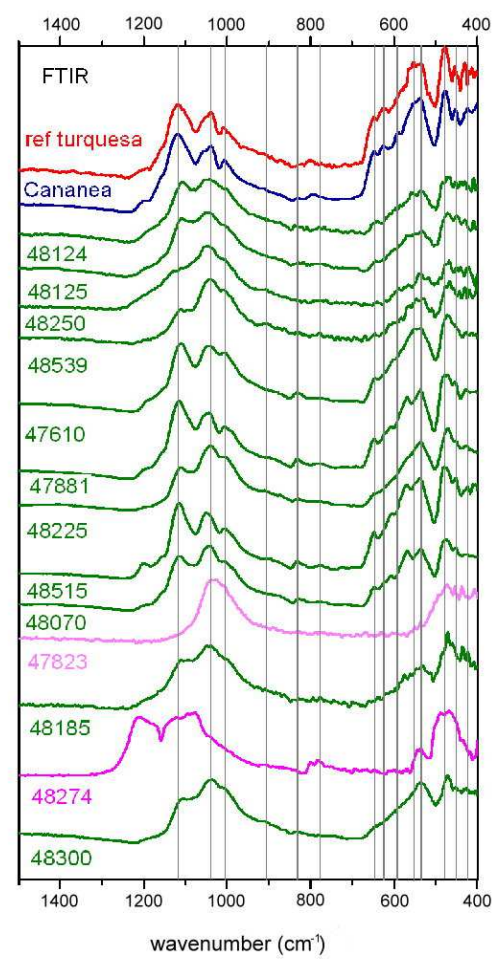

Figure 3. FTIR spectra of the pieces from Onavas. 


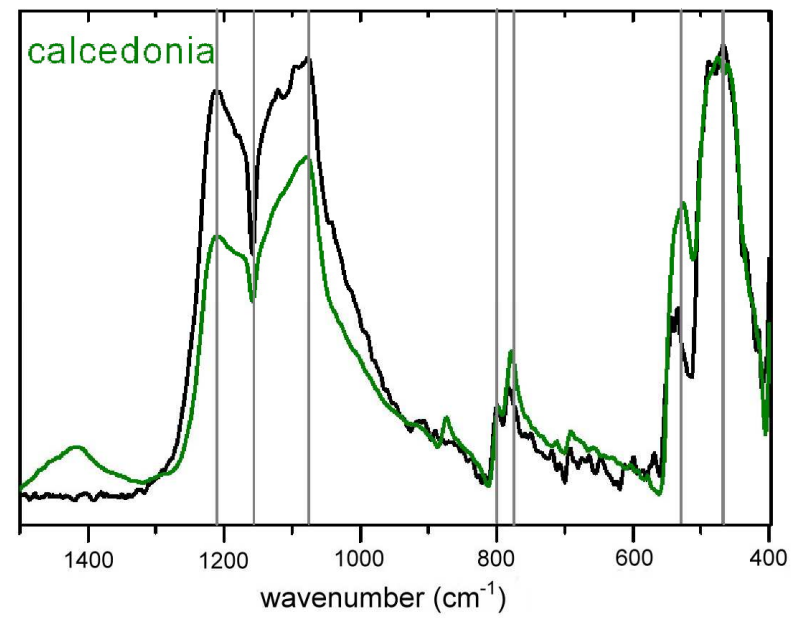

Figure 4. FTIR spectrum of the chalcedony object identified in Onavas.

\section{HOW THEY ARE MAKING THEM?}

According with the Experimental Archaeology paradigm, it is assumed that most of the human activities are regulated. This means that all of the artifacts produced or used follow a particular pattern that gives them specific characteristics (ASCHER 1961: 807; GÁNDARA 1990: 51). Under this line of thinking, the employment of similar tools and techniques, following certain patterns, will produce identical pieces in comparison with the archaeological ones (ASCHER, 1961: 793; COLES, 1979: 171; LEWENSTEIN, 1987: 7; VELÁZQUEZ, 2007: 52-54). Based on this theory and following the uniformity criteria that states the use of a particular tool made of a certain material, used in a standard procedure, and under particular conditions, will produce specific and characteristic traces that 
allow us to identify and distinguish each of them (BINFORD 1977: 7; TRINGHAM 1978: 180; VELÁZQUEZ 2007: 23).

Once a particular tool is used to produce a particular shape, texture or object, the obtained traces are systematically compared with those found at the archaeological items by: simple eye, magnifying glass of 20x, Optic Microscope at 10x, 30x, and 63x, and Scanning Electron Microscope (SEM) at 100x, 300x, 600x, and 1000x, all of them under controlled parameters. In the case of the SEM analysis, we employed HV mode, $10 \mathrm{~mm}$ of work distance, SEI signal, voltage of $20 \mathrm{kV}$, and spotsize of 47 . Following the methodology proposed by Velázquez Castro (2007) for the study and description of shell items adapted for lapidary objects, the manufacturing traces are described, focusing on the direction and size of bands and lines, its texture, and rugosity.

In order to identify the manufacturing process of the turquoise items from Onavas, the pieces were sent to the Workshop of Experimental Archaeology in Lapidary at the Templo Mayor Museum. The technological research on lapidary objects, with the backup of Experimental Archaeology and the characterization of the manufacturing traces with Optic Microscope (located at the Templo Mayor Museum) and Scanning Electron Microscope (SEM) (at the Electron Microscopy Laboratory of the Subdivision of Laboratories and Academic Backup of INAH), allows us to know with high precision the tools employed in each modification that the item presented. 
The performed analysis shows the following results:

Surfaces (Figure 5): With the stereoscopic microscope surface was described as smoothed and glossy crossed by very fine and well-marked scratches. Compared with the experimental sample traces we are able to say that the pieces were worn out without the aid of abrasives. To determine which type of tool was used, the samples were analyzed through the Scanning Electron Microscopy were fine lines of 3.5 microns that are agglomerated to form bands of approximately 10 microns thick are appreciated. These traces match the wear of experimental grinding made of sandstone slabs.

Polishing and Brightening (Figure 6): The Scanning Electron Microscopy shows flat surfaces with smooth lines of 1.3 microns thick with approximately 10 microns thick, that matches with experimental polishing with sand and burnishing with leather. 


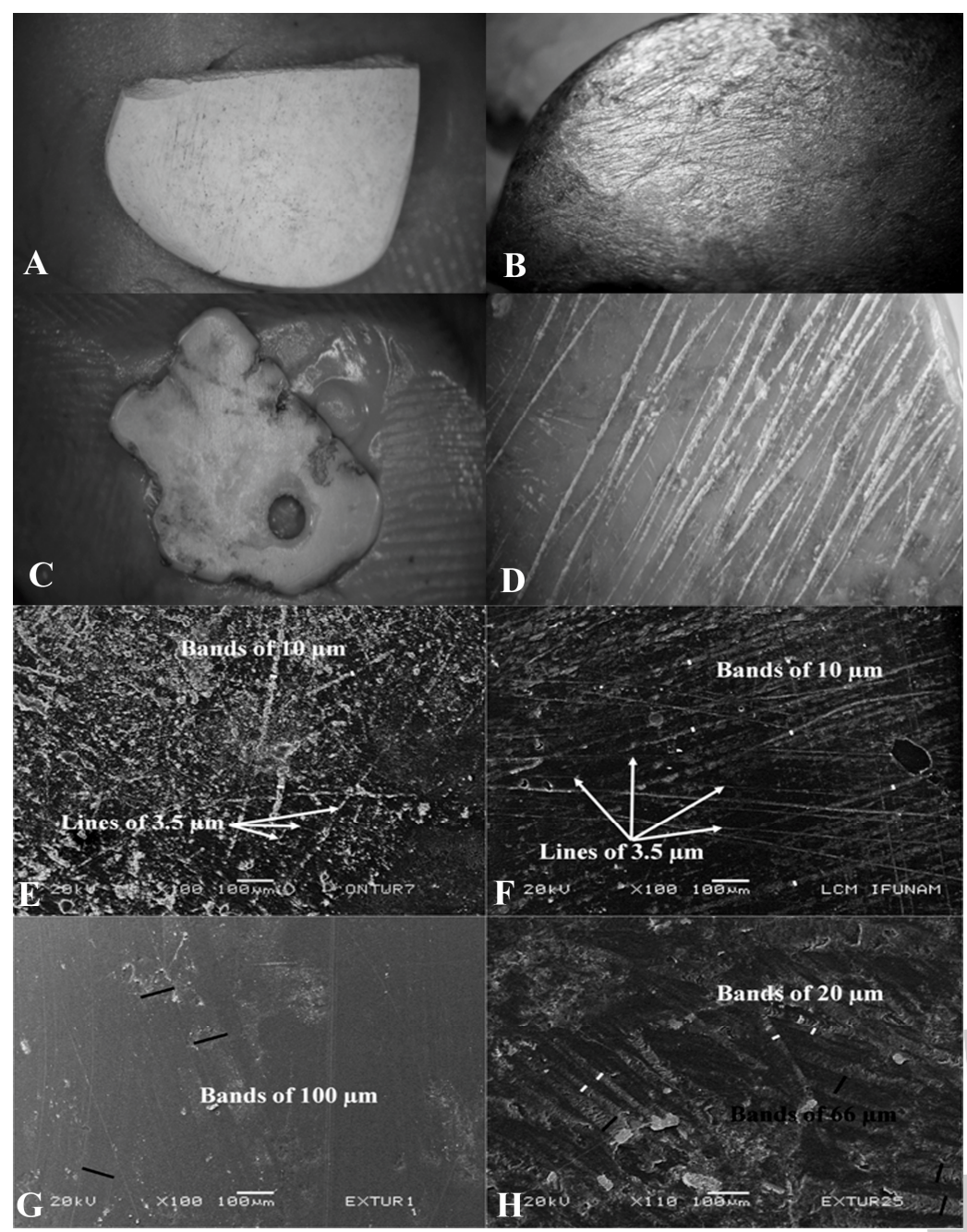

Figure 5: Analyses of surfaces: Archaeological inlay (A), experimental abrading with sandstone (B), archaeological pendant (C), experimental abrading with basalt (D), archaeological pendant (E), experimental abrading with sandstone $(F)$, experimental abrading with basalt $(G)$, and 
experimental abrading with limestone $(\mathrm{H})$. (Photos by Emiliano Melgar).

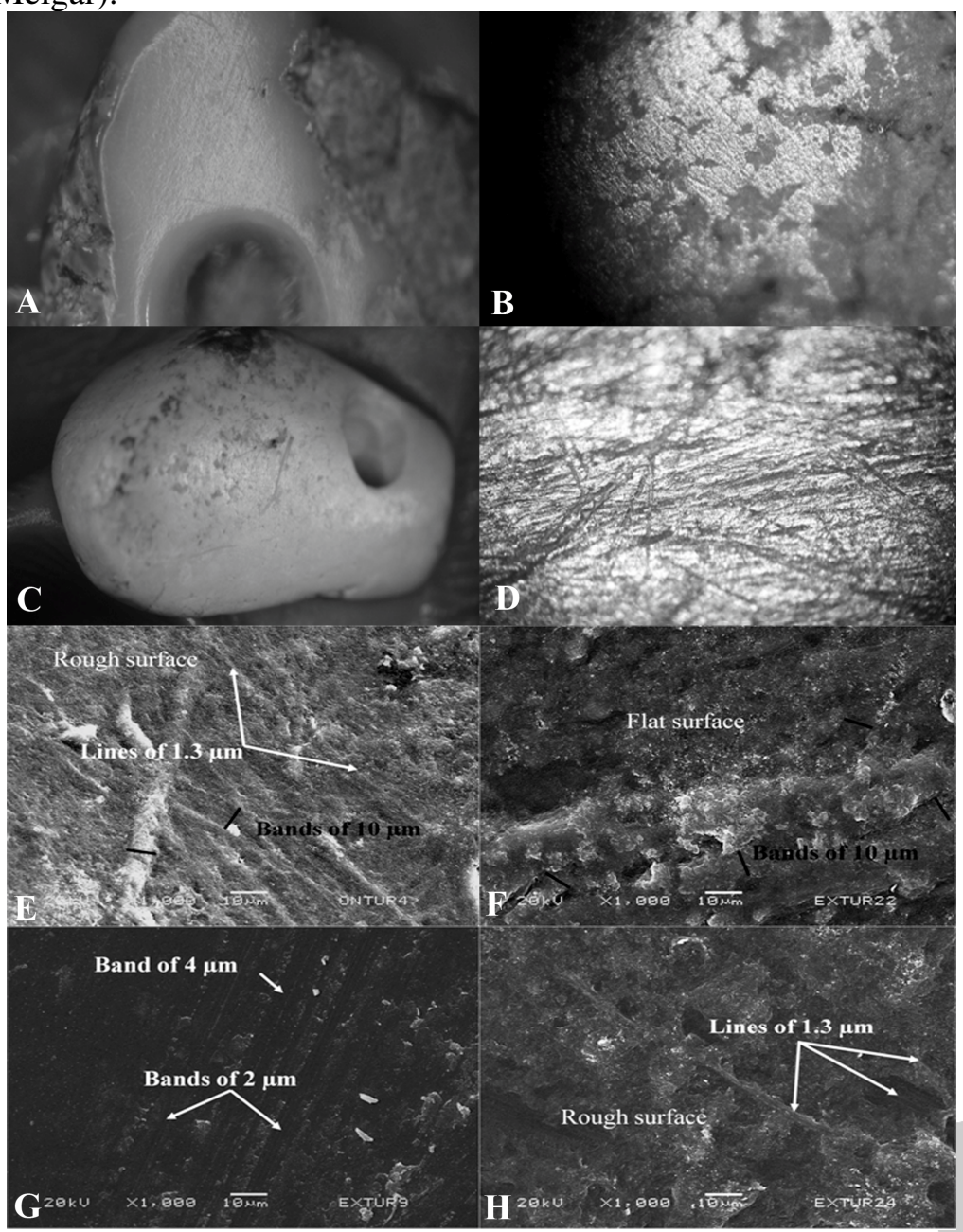

Figure 6: Analyses of polishing and brightness: archaeological bead (A), experimental brightening with leather (B), archaeological pendant $(\mathrm{C})$, experimental polishing with chert nodules (D), archaeological bead (E), experimental brightening with leather $(F)$, experimental polishing with chert nodules $(G)$, 
and experimental polishing with sand $(\mathrm{H})$. (Photos by Emiliano Melgar).

Edges (Figure 7): When observed through the stereoscopic microscope, all parts showed well defined straight lines. When compared with the experimental traces, we know that all were cut with stone tools. The detail provided by the Scanning Electron Microscopy shows thin lines between 0.7 to 1.3 microns width, like those obtained in experimental cuts made with obsidian blades or flakes.

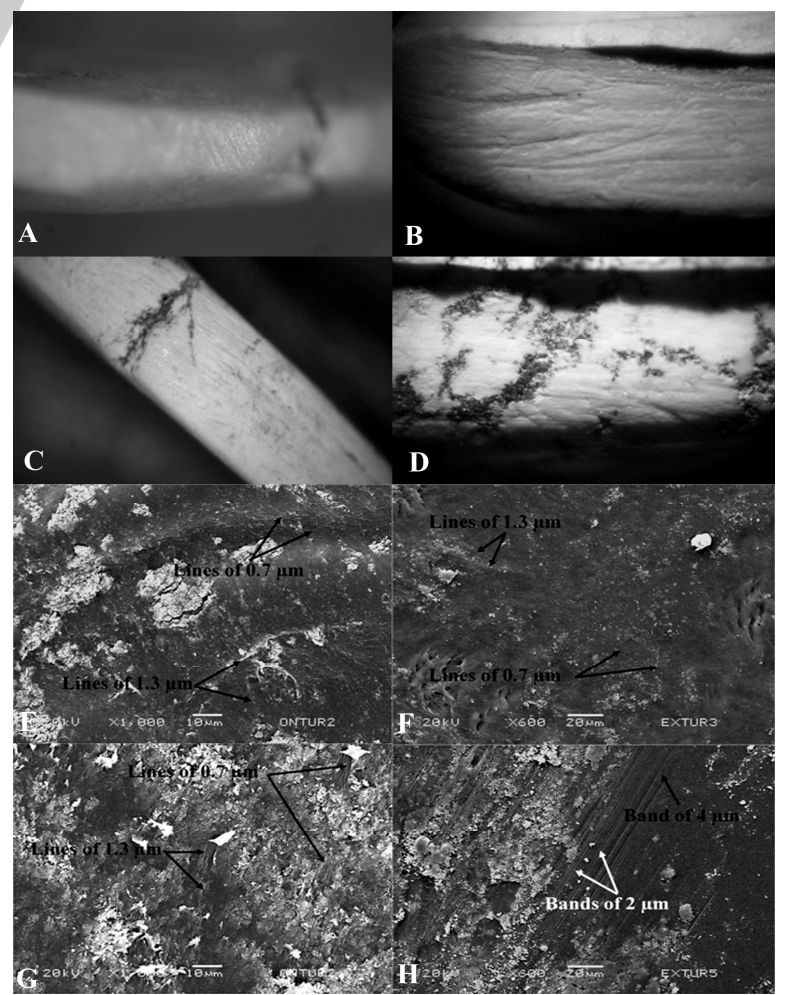

Figure 7: Analyses of edges: archaeological pendant (A), experimental cutting with obsidian (B), archaeological inlay (C), experimental cutting with chert (D), archaeological inlay (E), experimental cutting with obsidian (F), archaeological pendant (G), and experimental cutting with chert blades (H). (Photos by Emiliano Melgar). 
Perforations (Figure 8): The four samples have well-marked concentric circular scratches, similar to those obtained using stone drills without abrasives. Again, the Scanning Electron Microscopy shows sequences of bands between 2 and 4 microns thick, which is similar with the experimental drilling with chert drills or burins.

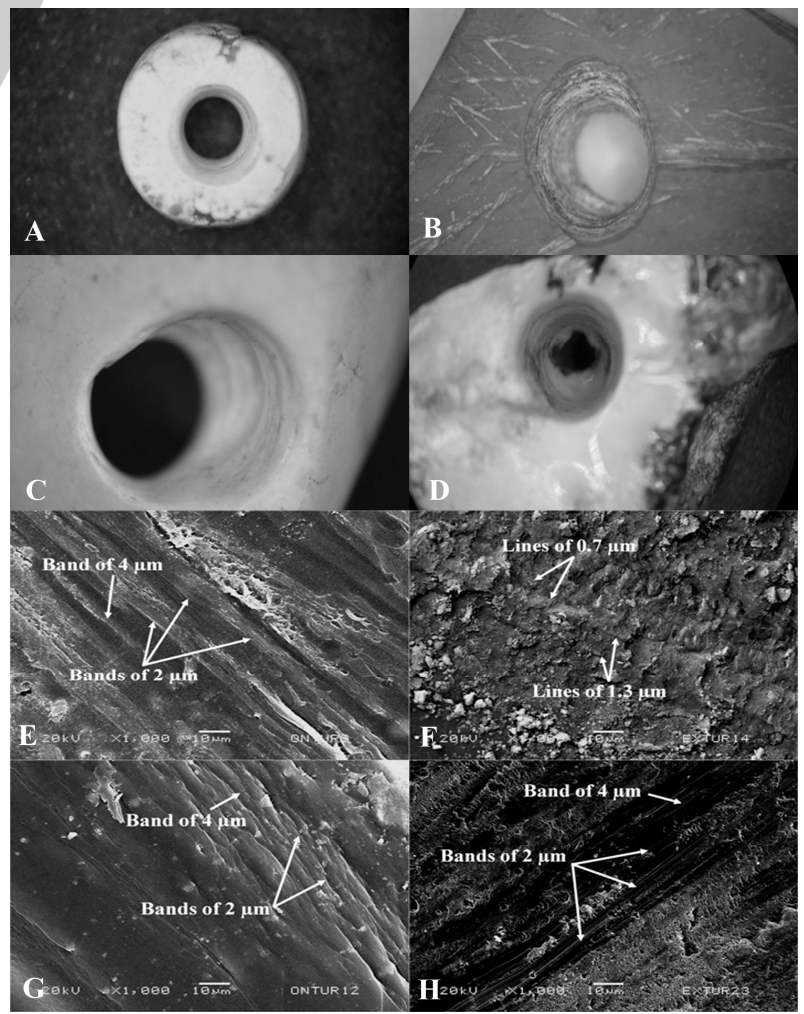

Figure 8: Analyses of holes: archaeological bead (A), experimental drilling with obsidian (B), archaeological pendant (C), experimental drilling with chert (D), archaeological bead (E), experimental drilling with obsidian $(\mathrm{F})$, archaeological pendant $(\mathrm{G})$, and experimental drilling with obsidian (H). (Photos by Emiliano Melgar). 


\section{CONCLUSIONS}

In summary, the results show that the Prehispanic community of the Onavas Valley indeed had access to non-local material such as turquoise. Although the sample was small, the analysis shows that almost all of them were "chemical" turquoise that arrives from the north, not from the traditional mining sources of the American southwest; but from an unknown location somewhere in the vicinity of Cananea, Sonora, some 400-450 km away, one of the seven possible Sonoran sources of this material listed by Weigand and Hardbottle (1997). Clearly more sampling of the area is need it especially those mention by Weigand and Hardbottle (1993), as well as from archaeological materials from the region, like those from the site of Huatabampo. Weigand (1997:30) mentions that the Guasave turquoise came from the Cerrillos mines from New Mexico. If the Onavas material is coming from other sources, is this mean Onavas is not part of this panregional market? Is Guasave acquiring its turquoise from the Chihuahua desert trade route instead of the Sonoran coast? This are more question that need to be address with more research in the coming years.

On the aspect of how these turquoise items had been made, the analysis illustrate that the abrading of them is with sandstone metates or lapstones, they are been cut with obsidian flakes or blades, punctuated or perforated with chert drills, and polished with sand and burnished with leather. The surface archaeological 
material found by the OVAP, illustrated that there is none sandstones metates or lapstones, there is obsidian flakes (n: 231), but no blades, and none chert drills. The archaeological evidence do not support the hypothesis that the Nebomes are working the turquoise, however some raw material of this material is present, but is also possible that the lithic workshops are not been identified in the surface and they are waiting to be found. Or indeed they are acquiring finished items from abroad. But, if the turquoise is not a local production, from where it came already manufactured? It is interesting that the sandstone lapstones and the obsidian flakes were recovered in the lapidary workshops from the San Juan Basin, especially in the Chaco Canyon (JUDD, 1954: plate 27; WINDES, 1993:223). But the technological analyses performed in some mosaics from this area does not match at all with the Onavas pieces, because the objects from the Anasazi were brightening with leather over the sandstone abrading and do not show sand as abrasive or polishing tool. Also, the drilling tool found in the Chaco Canyon is petrified wood, not chert (LEKSON, 1993:194-195). These technological differences could be as a result of drilling and finishing the partially worked pieces at Onavas from the Southwest, but the presence of raw materials (unworked turquoise fragments and nodules) allowed the possibility that the Nebomes manufactured their turquoise ornaments, or they are trade them raw to other regions.

Another interesting result is the green/blue chalcedony object, because in the minerals that the colleagues classified as "cultural" turquoise, this mineral is not 
listed (WEIGAND et al., 1977:16; WEIGAND, 1993: 300-303; NORTHROP, 1973: 17; BLOCK, 2007: 19; HULL et al., 2008: 1357). So, we think it could be incorporated in this category and show us that more detailed analyses of the stones employed by the Prehispanic is needed, because it could be more blue-green minerals that we do not know its existence in the archaeological contexts.

Finally, this paper illustrated that the Prehispanic Onavas Valley communities appear to have productive regional and extra-regional interactions. The valley may have served as a link in the material connection between the Sonoran coast and the Sierra Madre Occidental or interior beyond. Clearly, additional research is necessary to test this hypothesis, not only in the Onavas Valley but also at the coast and the Sierra Madre Occidental. In the cultural interactions research field, it is furthermore important to ask who is undertaking the trade. Which communities were involved and to what degree? Did the Prehispanic Nebomes travel to those communities or areas to get either raw material or finished items? Did foreign traders travel to Onavas to make the trade, or did they meet mid-way? Indeed, we answer some questions about the origin and making of the Onavas turquoise items, however more research still need to be done.

\section{BIBLIOGRAPHY}

ASCHER, R. 1961. “Experimental Archaeology”. American Anthropologist vol. 63, 793816.

ALMADA, F. R. 1990. Diccionario de Historia, Geografía y Biografía Sonorenses 21. Hermosillo: Instituto Sonorense de Cultura. 
ALVAREZ, A. M. 1999. "Estructura territorial Cahita en el momento del contacto. El caso de las naciones Yaqui y Mayo”. Noroeste de México, special edition, 111-118.

BINFORD, L. R. 1977. For Theory Building in Archaeology. Essays on Faunal Remains, Aquatic Resources, Spatial Analysis, and Systemic Modeling. Albuquerque: Academic Press.

BLOCK, M. P. 2007. Turquoise. Mines, Mineral, \& Wearable Art, Atglen, Pennsylvania: Schiffer Publishing Ltd.

COLES, J. 1979. Experimental archaeology. London: Academic Press.

EKHOLM, G. 1942. Excavations at Guasave Sinaloa, Mexico. New York: American Museum of Natural History.

GALLAGA, E. 2013. A Landscape of Interactions During the Late Prehispanic Period in the Onavas Valley, Sonora, Mexico. Tucson, Arizona: The University of Arizona, Arizona State Museum.

GÁNDARA Vázquez, M. 1990. "La analogía etnográfica como heurística: lógica muestreal, dominio etnográfico e historicidad". In Y. Sugiura and M. C. Serra Puche (eds.). Etnoarqueología. Primer Coloquio Bosch-Gimpera. Mexico City: Universidad Nacional de Autónoma de México, 43-82.

HULL, Sharon, Mostafa FAYEK, Frances Joan MATHIEN, Phillip SHELLEY y Kathy Roler DURAND. 2008. "A new approach to determining the geological provenance of turquoise artifacts using hydrogen and copper stable isotopes". Journal of Archaeological Science 35, 1355-1369.

INAH. 2012. "Descubren Cementerio Prehispánico en Sonora", Electronic Document. http://www.inah.gob.mx/index.php/boletines/17-arqueologia/6285-descubren-cementerioprehispanico-en-sonora. Accesed December 12, 2012.

JUDD, Neil M. 1954. The Material Culture of Pueblo Bonito. Washington D.C.: Smithsonian Institution. 
LACLAVETINE, K. 2008. Caracterisation non-destructive in situ de turquoises d'offrandes du Templo Mayor de México Tenochtitlan. Etude de provenance de turquoises par analyses de Fluorescence de Rayons X (XRF). Master's Thesis. Université Michel de Montaigne Bordeaux 3.

LEKSON, S. H. 1993. "Points and Drills of 29SJ 629". In T. C. Windes (ed.). The Spadefoot Toad Site: Investigations at 29SJ 629 Chaco Canyon, New Mexico: Artifactual and Biological Analyses. Volume II. Santa Fe: Chaco Center-Branch of Cultural Research-Division of Anthropology-National Park Service, 185-199.

LEWENSTEIN, S. M. 1987. Stone Tools at Cerros. The Ethnoarchaeological and Usewear Evidence. Austin: University of Texas Press.

NORTHROP, D. A. 1973. “Turquoise”. El Palacio, vol. 79 (1): 3-22.

MELGAR Tísoc, E. R. and R. B. SOLÍS Ciriaco. 2009. "Caracterización de huellas de manufactura en objetos lapidarios de obsidiana del Templo Mayor de Tenochtitlan." Arqueología 42, 118-134.

MELGAR Tísoc, E., R. SOLÍS Ciriaco and E. GONZÁLEZ Licón. 2010. "Producción y prestigio en concha y lapidaria de Monte Albán.” In E. Melgar, R. Solís and E. González (eds.). Producción de bienes de prestigio ornamentales y votivos de la América antigua. Miami: Syllaba Press, 6-21.

MONTANE, J. C. 1993. Atlas de Sonora. Hermosillo: Gobierno del Estado de Sonora.

PAILES, R. A. 1980. The Upper Río Sonora Valley in Prehispanic Trade. In C. L. Riley and B. C. Hedrick (eds.). New Frontiers in the Archaeology and Ethnohistory of the Greater Southwest. Springfield: Transactions of the Illinois State Academy of Science, 20-39.

PÉREZ BEDOLLA, R. G. 1996. "Geografía de Sonora”. In Historia general de sonora, tomo 1: periodo prehistórico y prehispánico. Gobierno del Estado de Sonora, Hermosillo, 97-150.

PÉREZ DE RIBAS, A. 1999. History of the Triumphs of Our Holy Faith amongst the Most Barbarous and Fierce Peoples of the New World. Tucson: University of Arizona 
Press.

POGUE, J. E. 1912. "The Aboriginal Use of Turquoise in North America". American Anthropologist vol. 14 (3): 437-466.

RUVALCABA Sil, J. L., L. BUCIO, M. E. MARÍN and A. VELÁZQUEZ. 2005. "Estudio por DRX y haces de iones de teselas de un disco de turquesas del Templo Mayor de Tenochtitlan”. In D. Mendoza Anaya, J. A. Arenas Alatorre and V. Rodríguez Lugo (eds.). La Ciencia de Materiales y su Impacto en la Arqueología. Volumen II. Mexico City: Academia Mexicana de Ciencia de Materiales, 95-111.

TRINGHAM, R. 1978. "Experimentation, Ethnoarchaeology, and the Leapfrog in Archaeological Methodology." In R. A. Gould (ed.). Explorations in Ethnoarchaeology. Albuquerque: University of New Mexico Press, 169-199.

VELÁZQUEZ Castro, A. 2007. La producción especializada de los objetos de concha del Templo Mayor de Tenochtitlan. México: Instituto Nacional de Antropología e Historia.

WEIGAND, P. C. 1993. Evolución de una civilización prehispánica: arqueología de Jalisco, Nayarit y Zacatecas. Zamora: El Colegio de Michoacán.

WEIGAND, P. C. 1997. "Minería prehispánica: La turquesa”. Arqueología Mexicana, vol. I (6), 26-33.

WEIGAND, P. C., and G. HARBOTTLE. 1993. "The Role of Turquoise in the Ancient Mesoamerican Trade Structure". In J. E. Ericson and T. G. Baugh (eds.). The American Southwest and Mesoamerica: Systems of Prehistoric Exchange. New York: Plenum Press, 159-178.

WEIGAND, P. C., and G. HARBOTTLE. 1995. "Minería prehispánica en las regiones noroccidentales de Mesoamérica, con énfasis en la turquesa". In E. Williams and P. C. Weigand (eds.). Arqueología del Occidente y Norte de México. Morelia: El Colegio de Michoacán, 115-138.

WEIGAND, Phil C., G. HARBOTTLE and E. V. SAYRE. 1977. "Turquoise Sources and Source Analysis: Mesoamerica and the Southwestern U.S.A.”. In T. K. Earle and J. E. 


\section{Clio Arqueológica 2020, V35N2, p.122-151, MURRIERA; TISOC}

DOI: 10.20891/clio.V35V2p122-151

Ericson (eds.). Exchange Systems in Archaeological Perspective. New York: Academic Press, 15-34.

WEST, R. C. 1993. Sonora: Its Geographical Personality. Austin: University of Texas Press.

WINDES, T. C. 1993. "Ground Stone, Chopping, and Percussion Tools from 29SJ 629”. In T. C. Windes (ed.). The Spadefoot Toad Site: Investigations at 29SJ 629 Chaco Canyon, New Mexico: Artifactual and Biological Analyses. Volume II. Santa Fe: Chaco Center-Branch of Cultural Research-Division of Anthropology-National Park Service, 201-268. 